\title{
HYGROSCOPICITY OF WOOD FROM Eucalyptus grandis AND Pinus taeda SUBJECTED TO THERMAL TREATMENT
}

\author{
Karina Soares Modes ${ }^{1}$, Elio José Santini², Magnos Alan Vivian ${ }^{3}$
}

(received: January 25, 2011; accepted: September 28, 2012)

\begin{abstract}
This study aimed to investigate the effect of the thermal treatment technique under two conditions-autoclave combined with electric oven and electric oven only-on the hygroscopic properties of wood from Pinus taeda L. and Eucalyptus grandis W. Hill ex Maiden, comparing them with results obtained for untreated wood. Three trees at age 25 years were sampled, with boards being removed at DBH level in order to make specimens $2.5 \times 2.5 \times 5.0 \mathrm{~cm}$ in size in the radial, tangential and axial direction respectively. In the combined treatment, specimens were subjected to thermal treatment in an autoclave set at $130^{\circ} \mathrm{C} / \pm 3^{\circ} \mathrm{C}$ and $\mathrm{kgf} /$ $\mathrm{cm}^{2}$ pressure for 3 hours, then to a conditioning period, followed by heat in an electric oven set at $160^{\circ} \mathrm{C} / \pm 1^{\circ} \mathrm{C}$ for the same time. Properties being evaluated included water absorption rate, volumetric swelling, water repellency effectiveness and anti-swelling efficiency. Results revealed that the thermal treatments being adopted were effective in reducing hygroscopicity and in increasing the dimensional stability of both species, revealing also that the combined autoclave and electric oven treatment provides best results.
\end{abstract}

Key words: Thermal treatment of wood, eucalyptus, pinewood, hygroscopic properties.

\section{HIGROSCOPICIDADE DA MADEIRA DE Eucalyptus grandis E Pinus taeda TRATADAS TERMICAMENTE}

\begin{abstract}
RESUMO: A presente pesquisa objetivou investigar o efeito da técnica de retificação térmica, empregada sob duas condições de tratamento: combinação de autoclave e estufa elétrica e uso de estufa elétrica nas propriedades higroscópicas das madeiras de Pinus taeda L. e Eucalyptus grandis W. Hill ex Maiden, comparando-as com os resultados obtidos para a madeira sem tratamento. Foram amostradas três árvores com 25 anos, e destas foram extraídas no DAP uma prancha para a confecção de corpos de prova de 2,5 $x 2,5 x$ $5,0 \mathrm{~cm}$, com orientação na direção radial, tangencial e axial, respectivamente. No tratamento de combinação, as peças foram submetidas a termorretificação em autoclave a $130^{\circ} \mathrm{C} / \pm 3^{\circ} \mathrm{C}$ e pressão de $2 \mathrm{~kg} f / \mathrm{cm}^{2}$, por 3 horas e, após um período de condicionamento, submetidas ao calor em estufa elétrica a $160^{\circ} \mathrm{C} / \pm 1^{\circ} \mathrm{C}$, pelo mesmo período. As propriedades avaliadas consistiram na taxa de absorção de água, inchamento volumétrico, efetividade de repelência à água e eficiência antiinchamento. Os resultados obtidos indicaram que os tratamentos térmicos empregados, foram eficientes na redução da higroscopicidade e aumento da estabilidade dimensional de ambas as espécies, sendo que a combinação autoclave e estufa elétrica fornece os melhores resultados.
\end{abstract}

Palavras-chave: Termorretificação da madeira, eucalipto, pinus, propriedades higroscópicas.

\section{INTRODUCTION}

Due to some peculiarities, such as dimensional movement, use of wood is restricted to specific applications. Modifying processes are designed to improve wood properties, that way restricting water exchange between the wood material and the surrounding environment. These modification processes can be divided into four types: chemical, thermal, surface and impregnation, among which thermal modification is the method that has evolved the most in recent years in commercial terms, mainly due to the low cost involved in the process.
The underlying technique is to use heat in the modifying processes ('thermal rectification'), which consists in subjecting wood samples to a range of $120^{\circ} \mathrm{C}$ to $200^{\circ} \mathrm{C}$, from high drying temperature to torrefaction temperature, that way promoting considerable chemical changes in cellulose, hemicellulose and lignin polymers and obtaining a differentiated material similar to wood in normal conditions, yet with lower hygroscopicity but higher dimensional stability and biological resistance.

Reduction in hygroscopicity occurs through modification of the chemical structure of some wood components, to a greater or lesser degree, thereby

\footnotetext{
${ }^{1}$ Forest Engineer, Professor M.Sc. in Forest Engineering - Universidade Federal de Rondônia - Departamento de Engenharia Florestal Campus Rolim de Moura - Av. Norte-Sul, 7300 - 78987-000 - Rolim de Moura, RO, Brazil - ksmodes@gmail.com

${ }^{2}$ Forest Engineer, Professor Ph.D. in Forest Engineering - Universidade Federal de Santa Maria - Centro de Ciências Rurais - Departamento de Ciências Florestais - Av. Roraima, 1000 - 97105-900 - Santa Maria, RS, Brazil - ejsantini@gmail.com

${ }^{3}$ Forest Engineer, Ph.D. Candidate in Forest Resources - Universidade de São Paulo/USP - Escola Superior de Agricultura "Luiz de Queiroz"/ESALQ - Departamento de Ciências Florestais - Av. Pádua Dias 11 - 13418-900 - Piracicaba, SP, Brazil magnosalan@yahoo.com.br
} 
preventing reabsorption of water (PONCSAK et al., 2006).

According to Moura et al. (2008), during the heating process, the hydrophilic polysaccharides of wood (hemicelluloses) volatilize, reducing the free hydroxyl groups $(\mathrm{OH})$ to which water molecules would normally attach.

According to Homan et al. (2000), when thermally treating wood, heat acts on these polymer regions and cause changing phenomena such as recombination (crosslinking), substitution of $\mathrm{OH}$ groups with other groups of hydrophobic nature, removal of $\mathrm{OH}$ groups or undesirable chain cleavage, all of which restrict the ability of wood to exchange water with the atmosphere.

According to Poncsak et al. (2006), substitution of $\mathrm{OH}$ groups by hydrophobic groups is due, in these treatments, to the number of $\mathrm{OH}$ hydrophilic groups being reduced and being substituted with hydrophobic $O$-acetyl groups. According to Sundqvist (2004), these groups are formed by degradation of hemicellulose and released from wood in the form of acetic acid.

So far, research projects developed in Brazil on the subject are very incipient and those few works that have been published address mainly the effect of combining different temperatures and times of treatment on wood properties, which calls for research to focus on other variables potentially influencing results. Also, approaches so far have dealt with treatments using either electric oven or autoclave as the heating environment.

In an attempt to break new ground in research about methods of applying heat to wood, this study aims to evaluate the effect of thermal treatment using autoclave and electric oven combined and using electric oven only on the hygroscopic properties of wood from Pinus taeda and Eucalyptus grandis.

\section{MATERIAL AND METHODS}

\subsection{Preparation and treatment of material}

Wood samples from Eucalyptus grandis W. Hill ex Maiden and Pinus taeda L. were obtained from stands owned by the state foundation for agricultural research ('FEPAGRO Florestas'), located in Boca do Monte, Santa Maria district - RS.

For each species, three trees at age 25 years were sampled. A central board was removed from each at DBH level in order to make specimens $2.5 \times 2.5 \times 5.0 \mathrm{~cm}$ in size in the radial, tangential and axial directions respectively. After a conditioning period at $20^{\circ} \mathrm{C}$ and $65 \% \mathrm{RH}$, followed by stabilization, samples were subjected to two methods of thermal treatment: first treated in an autoclave and, then subjected to an acclimatizing period, then into an oven (combined treatment), or treated in an oven only (oven treatment), whereas the control samples (untreated wood) remained under temperature-controlled conditions.

The variation in temperature as a function of time for different treatments is illustrated in Figure 1. The duration of each treatment started to be computed the moment the required temperature was attained.

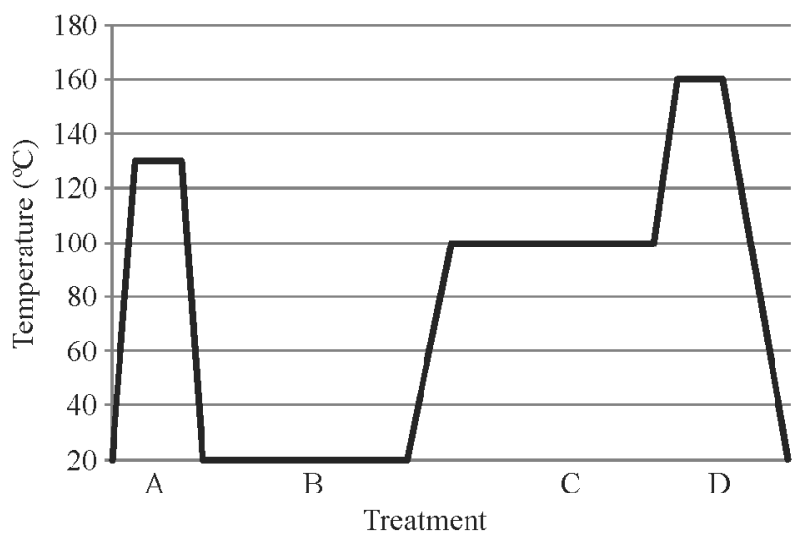

Figure 1 - Stages of combined and oven only treatments. (A) Thermal treatment using an autoclave set at $130 \pm 3^{\circ} \mathrm{C}$ temperature and $2 \mathrm{kgf} / \mathrm{cm}^{2}$ pressure for 3 hours; (B) Conditioning stage in a temperature-controlled chamber at $20^{\circ} \mathrm{C}$ and $65 \% \mathrm{RH}$ to constant weight; (C) Predrying in an oven at $100 \pm 1^{\circ} \mathrm{C}$ for 24 hours; (D) Thermal treatment in an electric oven set at $160 \pm 1^{\circ} \mathrm{C}$ for 3 hours; $\mathrm{A}+\mathrm{B}=$ Oven treatment; $\mathrm{A}+\mathrm{B}+\mathrm{C}+\mathrm{D}=$ Combined treatment.

Figura 1 - Fases dos tratamentos de combinação e estufa. (A) Tratamento de termorretificação em autoclave a temperatura de $130 \pm 3^{\circ} \mathrm{C}$ e pressão de $2 \mathrm{kgf} / \mathrm{cm}^{2}$ por 3 horas; $(B)$ Período de condicionamento em câmara climatizada a $20^{\circ} \mathrm{C} 65 \%$ UR até peso constante; (C) Secagem prévia em estufa a $100 \pm 1{ }^{\circ} \mathrm{C}$ por 24 horas; (D) Tratamento de termorretificação em estufa elétrica a $160 \pm 1^{\circ} \mathrm{C}$ por 3 horas; $A+B=$ Tratamento em estufa; $A+B+C+D=$ Tratamento combinado.

For the thermal treatment of samples, a laboratory autoclave was used with internal dimensions of approximately $79 \times 85 \times 125 \mathrm{~cm}$ (225 1 capacity), along with an electric forced-air circulation oven with digital temperature control. All material was subsequently conditioned in a temperature-controlled chamber until weight was stabilized, and then subjected to hygroscopicity tests.

Cerne, Lavras, v. 19, n. 1, p. 19-25, jan./mar. 2013 


\subsection{Evaluated parameters}

\subsubsection{Water absorption rate}

To evaluate this parameter, samples were subjected to 2 to 4 cycles (immersion/drying) consisting of total immersion in water for 24 hours using a plastic bowl, followed by drying in an oven set at $60^{\circ} \mathrm{C}$ to constant weight.

At the end of each stage, samples were weighed using a digital scale accurate to 0.01 grams. Based on this information, the behavior of samples was analyzed in all three treatments, after comparing the first and the last cycle.

$$
t=\frac{M_{u}-M_{s}}{M_{s}} \times 100
$$

Equation 1

$t=$ water absorption rate of samples, $\% ; M_{u}=$ sample weight after immersion in water for $24 \mathrm{~h}, \mathrm{~g} ; M_{s}=$ sample weight after oven drying at $60^{\circ} \mathrm{C}, \mathrm{g}$.

\subsubsection{Water repellency effectiveness (ERA)}

Water repellency effectiveness was calculated based on the water absorption rates of treated samples, under two conditions (combined and oven only), and untreated samples (control).

$$
E R A=\frac{t_{1}-t_{2}}{t_{1}} \times 100
$$

Equation 2

$E R A=$ water repellency effectiveness, $\% ; t_{1}=$ water absorption rate of untreated samples; $t_{2}=$ water absorption rate of treated samples.

\subsubsection{Volumetric swelling coefficient}

This coefficient was determined in the radial, tangential and axial directions in such way that, at the end of each water immersion stage, and at the end of the oven drying process at $60^{\circ} \mathrm{C}$, measurements could be taken at the same position, using a digital caliper.

$$
I=\left(\frac{V_{2}-V_{1}}{V_{1}}\right) \times 100
$$

Equation 3

$I=$ volumetric swelling coefficient, $\% ; V_{2}=$ volume of treated wood after immersion in water for $24 \mathrm{~h}, \mathrm{~cm}^{3} ; V_{1}=$ volume of wood after drying at $60^{\circ} \mathrm{C}, \mathrm{cm}^{3}$.

\subsubsection{Anti-swelling efficiency (EAI)}

Based on the previous calculation, samples were analyzed for any reduction in swelling as a result of thermal treatment.
$E A I=\left(\frac{I_{2}-I_{1}}{I_{2}}\right) \times 100$

$E A I=$ anti-swelling efficiency, $\% ; I_{1}=$ volumetric swelling coefficient of treated wood, $\% ; I_{2}=$ volumetric swelling coefficient of untreated wood, $\%$;

\subsubsection{Apparent specific mass}

Using weight and volume measurements, as determined at each stage of oven drying to constant weight, the specific mass of samples was then calculated to determine any oscillation in the course of the evaluation cycles.

$\rho=\frac{M}{V}$

Equation 5

$\rho=$ specific apparent mass, under a drying condition of $60^{\circ} \mathrm{C}, \mathrm{g} / \mathrm{cm}^{3} ; M=$ sample weight under the same condition, $\mathrm{g} ; V=$ sample volume under the same condition, $\mathrm{cm}^{3}$.

\subsection{Statistical analysis}

The experiment was laid out in a completely randomized block design. Values of water absorption rate, volumetric swelling, water repellency effectiveness and antiswelling efficiency corresponding to the first and last cycles were computed into the proposed design and used for checking any significant differences. For sources of variation detected as being significant by the F-test, the Tukey test was applied at a 95\% significance level.

\section{RESULTS AND DISCUSSION}

Figure 2 provides water absorption percentages and corresponding volumetric swelling for Pinus taeda and Eucalyptus grandis, along with variations in apparent specific mass, obtained throughout the cycles of water immersion and subsequent oven drying of samples.

The pinewood samples had a large number of cracks from the very end of cycle 2 of water immersion and subsequent oven drying, thus precluding the continuity of observations. According to Esteves and Pereira (2009), softwoods are more susceptible to tangential cracks in adult portions of wood and in portions with narrow annual rings and/or with abrupt transition between spring and autumn wood.

In pinewood, the effect of thermal treatment was not as expected. In both the combined and oven only treatments, the increase in water absorption rate was accompanied by a corresponding increase in volumetric swelling of samples. The control sample, on the other hand, had an increase in absorption rate from cycle 1 to cycle 2 but was accompanied by a corresponding reduction in volumetric swelling.

Cerne, Lavras, v. 19, n. 1, p. 19-25, jan./mar. 2013 

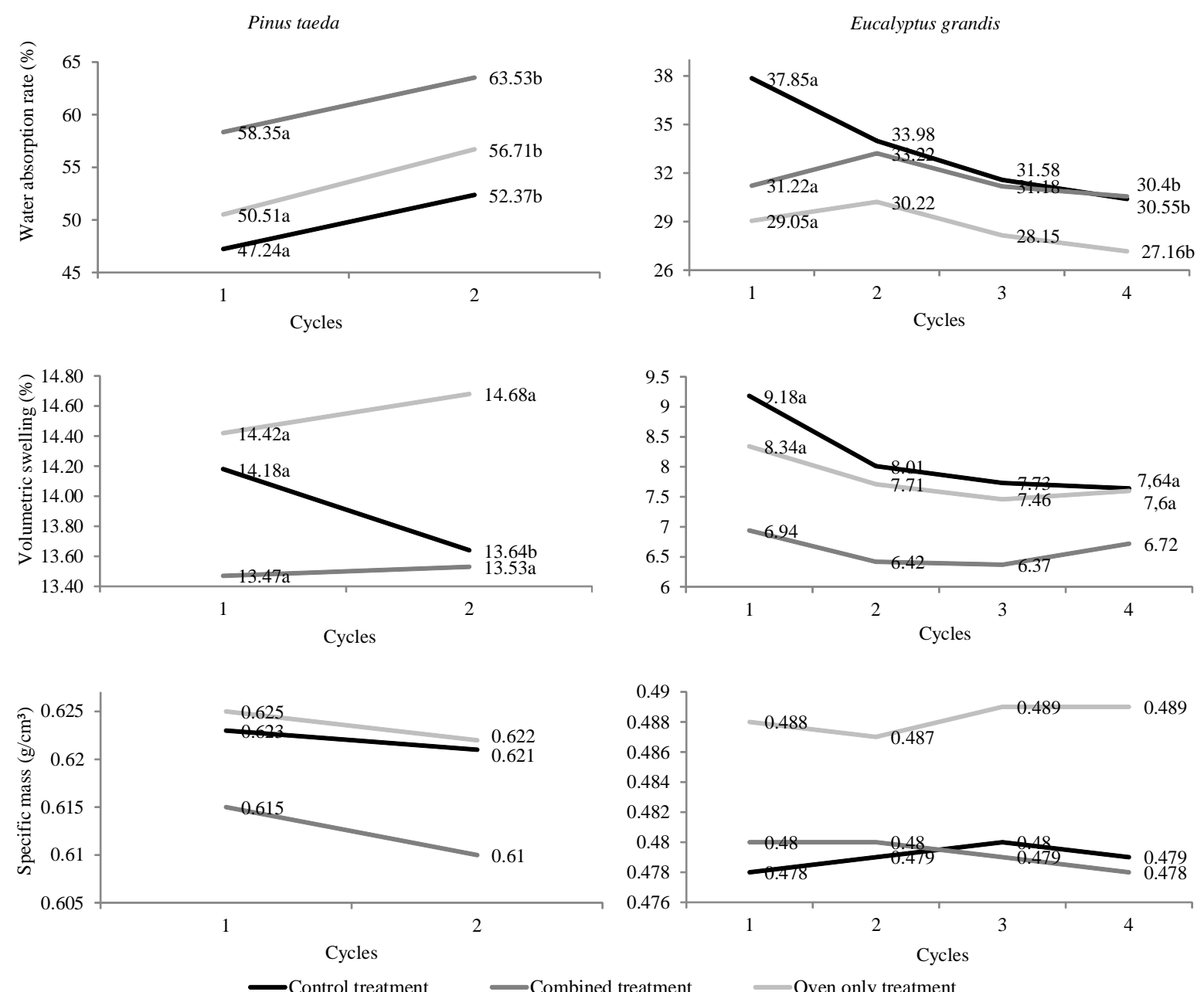

Figure 2 - Water absorption rate, volumetric swelling and apparent specific mass for Pinus taeda and Eucalyptus grandis throughout cycles. * $=$ Means followed by the same letter do not differ statistically from each other at the 5\% probability level by the Tukey test.

Figura 2 - Taxa de absorção de água, inchamento volumétrico e massa específica aparente da madeira de Pinus taeda e Eucalyptus grandis no decorrer dos ciclos. *= Médias seguidas pela mesma letra não diferem estatisticamente entre si ao nível de $5 \%$ de probabilidade pelo teste de Tukey.

As for eucalyptus wood, the benefits of thermal treatments in reducing hygroscopicity were more clearly noticed, since the control treatment provided higher values of volumetric swelling and corresponding rate of water absorption than treated wood.

Regarding the thermal treatments, an inverse behavior was noted between cycles 1 and 2 , in which a reduction was noted in the volumetric swelling of samples, despite having absorbed a larger amount of moisture. In subsequent cycles, a reduction was noted in swelling as promoted by corresponding reduction in the absorption rate and, toward the end of the evaluation, a clear loss is noted in the efficiency of the thermal treatment, with an increase in the volumetric swelling of the pieces, despite the reduced water absorption.

For Mohebby and Sanaei (2005), water absorption in treated samples as promoted by heat is due to wood becoming more porous on account of ray cracking and hemicellulose removal. According to these authors, reduction in water absorption by untreated samples may be related to a hysteresis phenomenon occurring to wood when drying cycles are used after water immersion.

\section{Cerne, Lavras, v. 19, n. 1, p. 19-25, jan./mar. 2013}


Esteves and Pereira (2009) suggest that wood pore sizes increase with thermal treatment, perhaps due to removal of cell wall components. This fact may be the reason why water absorption is greater in treated wood.

According to Sundqvist (2004), under a temperature range of $100^{\circ} \mathrm{C}$ to $160^{\circ} \mathrm{C}$, the range in which this study was conducted, the chemical and structural profile of hemicelluloses undergoes a slight change, starting at $60^{\circ} \mathrm{C}$ and evolving to strong changes at $150^{\circ} \mathrm{C}$; with lignin, slight change predominates in the same range and go beyond $160^{\circ} \mathrm{C}$. Cellulose, on the other hand, starts undergoing slight change only at $120^{\circ} \mathrm{C}$, remaining so up to approximately $200^{\circ} \mathrm{C}$, when strong changes start to happen in this component of the cell wall.

For Charani et al. (2007), water absorption typically decreases in all thermally treated woods. Yet, when cracks start to appear, they are accountable for increased water absorption, a result of the damage caused to the physical structure of wood with the increasing temperatures used in treatments.

With respect to specific mass, the graphs of both species reveal very subtle oscillations, attributable to measurement procedures, therefore they fail to show a marked tendency influencing the hygroscopic behavior of samples.

As regards changes caused by thermal treatments in comparison with control samples, effects can be better understood by viewing Figure 3, as it provides test results for water repellency effectiveness (ERA) and anti-swelling efficiency (EAI) for Pinus taeda and Eucalyptus grandis, along with the means test between the first and the last evaluation cycles.

According to Norimoto and Gril (1993), as cited by Del Menezzi (2006), a 0\% value for these variables means that the treatment had no effect on dimensional stabilization, while a negative value translates as a deleterious effect of the treatment (increase in dimensional movement), and a $100 \%$ value translates as fully stabilized wood and therefore a highly effective treatment.

Regarding water repellency effectiveness in pinewood, the thermal treatments were noted to favor water absorption, and this was reflected by the negative values of the variable, particularly in pieces treated by the combined method, as they tended to promote an increase in effectiveness, or reduced water absorption, from cycle 1 to cycle 2 .
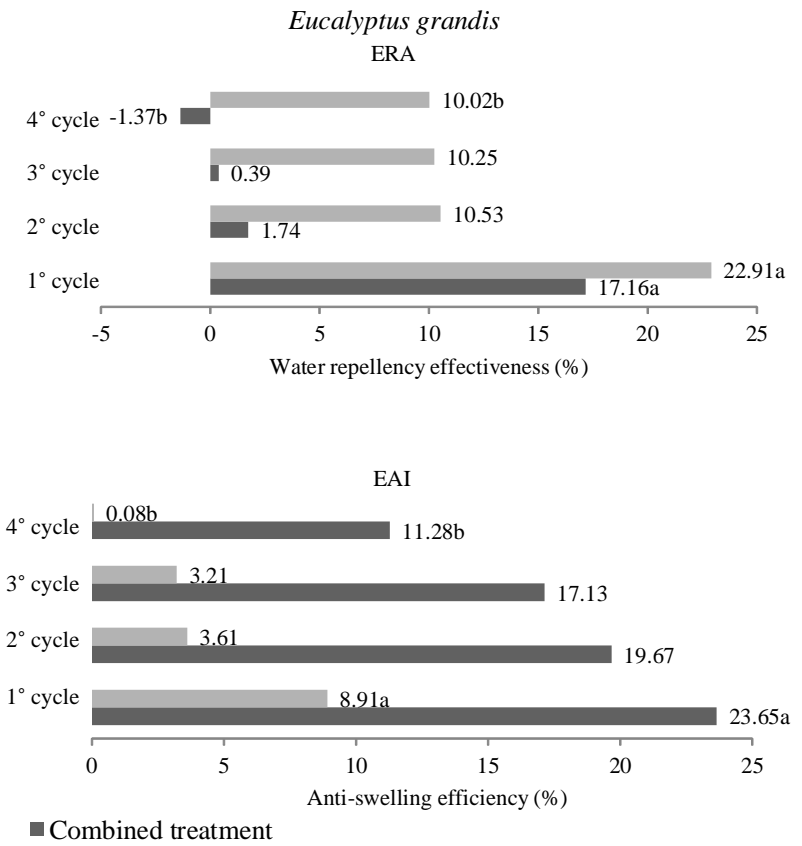

Figure 3 - Water Repellency Effectiveness (ERA) and Anti-Swelling Efficiency (EAI) values found in Pinus taeda and Eucalyptus grandis in the first and last evaluation cycles. *= Means followed by the same letter do not differ statistically from each other at the $5 \%$ probability level by the Tukey test.

Figura 3 - Valores de Efetividade de Repelência à Água (ERA) e Eficiência Anti Inchamento (EAI) apresentados pela madeira de Pinus taeda e Eucalyptus grandis no $1^{\circ}$ e último ciclo de avaliação. * = Médias seguidas pela mesma letra não diferem estatisticamente entre si ao nível de $5 \%$ de probabilidade pelo teste de Tukey. 
In the oven only treatment, water absorption favored by the treatment was much reduced and, unlike the combined treatment, tended to a slight increase, or reduced effectiveness, throughout the same cycles.

In regard to anti-swelling efficiency in that species, the combined treatment clearly proved more advantageous to dimensional stabilization of samples, promoting a reduction in volumetric swelling, as demonstrated by the positive values found for this variable, undergoing a drastic reduction in efficiency between cycles. The oven only treatment promoted increased dimensional instability, very pronounced from cycle 1 to cycle 2 and in such way that values differed statistically, going from $-1.85 \%$ to $-7.78 \%$.

Regarding water repellency effectiveness in eucalyptus wood, it was noted that both treatments promoted positive effects, in particular the oven only treatment, whose values had a slighter reduction over the last cycles, maintaining effectiveness values above $10 \%$. In the combined treatment, effectiveness was lower and also had a more pronounced reduction in the course of evaluations, having even a deleterious effect in the final cycle.

In reference to anti-swelling efficiency in that species, the combined treatment added greater dimensional stability to the samples, maintaining reduction in swelling above $10 \%$, whereas in the oven only treatment efficiency decreased considerably, having hardly any effect in the last cycle.

In a study with Fagus orientalis Lipsky, with wood being treated at $160^{\circ} \mathrm{C}$ for 4 hours in presence of steam, Mohebby and Sanaei (2005) found anti-swelling efficiency values of $11 \%$ after the last cycle of immersion/ drying, virtually the same value found for E. grandis in this study.

The $23.65 \%$ value found in cycle 1 for wood from $E$. grandis is similar to the $24 \%$ found for anti-swelling efficiency by Santos (2000), who worked with Eucalyptus yet at a temperature of $180^{\circ} \mathrm{C}$ and making no mention of time.

The percentages of reduction in volumetric swelling found between the first and last evaluation cycles were lower than results reported by Charani et al. (2007), who, in a study with Fagus orientalis with wood being treated at $160^{\circ} \mathrm{C}$ for 3 hours in presence of steam, found an antiswelling efficiency value of approximately $35 \%$ in cycle 1 reducing to $18.99 \%$ after cycle 7 of sample immersion/ drying.

\section{Cerne, Lavras, v. 19, n. 1, p. 19-25, jan./mar. 2013}

In the same work and adopting different treatment times and temperatures, the above authors also found a reduction in anti-swelling efficiency with application of more than one consecutive cycle, as applied to the samples, after the treatment.

\section{CONCLUSIONS}

In Pinus taeda, the thermal treatment increased water absorption, particularly the combined method, which in turn promoted a reduction in volumetric swelling.

As for Eucalyptus grandis, the thermal treatment reduced water absorption, particularly the oven only treatment. Yet, lower values of volumetric swelling were found using the combined treatment.

After being subjected to the thermal treatment, wood samples acquired interesting hygroscopic characteristics that could make them suitably usable in the manufacture of doorjambs, window frames, flooring, playground pieces and garden furniture.

\section{REFERENCES}

CHARANI, P. R.; ROVSHANDEH, J. M.; MOHEBBY, B.; RAMEZANI, O. Influence of hydrothermal treatment on the dimensional stability of beech wood. Caspian Journal of Environmental Sciences, Guilan, v. 5, n. 2, p. 125-131, 2007.

DEL MENEZZI, C. H. S. Instabilidade dimensional da madeira e de seus subprodutos: causas, consequiências e prevenção. Brasília: Comunicações Técnicas Florestais, 2006. $37 \mathrm{p}$.

ESTEVES, B. M.; PEREIRA, H. M. Wood modification by heat treatment: a review. BioResources, Oxford, v. 4, n. 1, p. 370-404, 2009.

HOMAN, W.; TJEERDSMA, B.; BECKERS, E.; JORISSEN, A. Structural and other properties of modified wood. In: WORLD CONFERENCE ON TIMBER ENGINEERING, 5., 2000, Bern. Proceedings... Bern: CIB-W18, 2000. CDROM.

MOHEBBY, B.; SANAEI, I. Influences of the hydro-thernal treatment on physical properties of beech Wood (Fagus orientalis). In: ANNUAL MEETING BANGALORE, 36., 2005, New Delhi. Proceedings... New Delhi: Tarbiat Modarress University, 2005. 
MOURA, L. F. de; BRITO, J. O.; NOLASCO, A. M.; ULIANA, L. R. Efeito da termorretificação sobre as propriedades de usinagem de Eucalyptus grandis e Pinus caribaea var. hondurensis. In: SIMPÓSIO DE CIÊNCIA E TECNOLOGIA DA MADEIRA DO ESTADO DO RIO DE JANEIRO, 1., 2008, Seropédica. Anais... Seropédica: UFFRJ, 2008. p. 7-8.

PONCSÁK, S.; KOCAEFE, D.; BOUAZARA, M.;

PICHETTE, A. Effect of high temperature treatment on the mechanical properties of birch (Betula papyrifera).
Wood Science and Technology, Les Ulis, v. 40, n. 8, p. 647-663, 2006.

SANTOS, J. A. Mechanical behaviour of Eucalyptus wood modified by heat. Wood Science and Technology, Les Ulis, v. 34 , n. 1, p. 39-43, June 2000.

SUNDQVIST, B. Colour changes and acid formation in wood during heating. 2004. $154 \mathrm{f}$. Thesis (Doctoral in Wood Material Science) - Lulea University of Technology, Lulea, 2004. 
